СК. Ю. Литвин ${ }^{1}$, Л. Р. Шостакович-Корецька ${ }^{1}$, Л. О. Гавриленко ${ }^{2}$

Д3 “Дніпропетровська медична академія", Кз “Дніпропетровська міська клінічна лікарня № 21 імені проф. Є. Г. Попкової Дніпропетровської обласної ради" 2

\title{
ДІАГНОСТИЧНЕ ТА ПРОГНОСТИЧНЕ ЗНАЧЕННЯ ВИЗНАЧЕННЯ ІНТЕРФЕРОНУ-ГАММА В СПИННОМОЗКОВІЙ РІДИНІ ПРИ ВІЛ-АСОЦІЙОВАНИХ НЕВРОЛОГІЧНИХ ЗАХВОРЮВАННЯХ
}

\begin{abstract}
Резюме. Неврологічні захворювання розвиваються у більшості пацієнтів із ВІЛ, мають високу летальність, переважну частку якої складають опортуністичні інфекції ЦНС. Інтерферон-гамма (IFN-y) є одним із головних цитокінів, які мають важливе значення для розвитку нейропатогенезу ВІЛ.

Мета дослідження - вивчити зміни вмісту IFN-y в крові й спинномозковій рідині та дослідити його зв'язок з імунологічним статусом та вірусним навантаженням ВІЛ РНК при ВІЛ-асоційованих неврологічних захворюваннях.

Матеріали і методи. Обстежено 48 пацієнтів із ВІЛ-інфекцією та захворюваннями ЦНС, зумовленими опортуністичними інфекціями, у віці 21-54 роки. В структурі захворювань ЦНС переважали церебральний туберкульоз - 15 (31,3\%) і вірусні енцефаліти (ЕБВ, ЦМВ, HSV) - 11 (22,9 \%) пацієнтів. Групу порівняння склали 7 здорових донорів відповідного віку. Bміст IFN-y в крові та у спинномозковій рідині (СМР) визначали за методом ІФА. Для статистичної обробки результатів дослідження використовували програми Statistica v.6.1® i MedCalc v.11.5.0 (free download).

Результати досліджень та їх обговорення. Визначено суттєві розбіжності між вмістом IFN-y у CMP залежно від наслідку хвороби - медіана показника в померлих пацієнтів втричі перевищувала таку у хворих, які вижили, $-9,0(6,0-12,0)$ пг/мл проти 3,0 $(1,0-7,0)$ пг/мл ( хворих та несприятливим прогнозом ( $r s=0,48 ; p<0,001)$. Встановлено прямі взаємозв'язки між вмістом IFN-y у CMP і вірусним навантаженням ВІЛ PHК як у CMP ( $r s=0,44 ; p<0,01)$, так і в крові $(r s=0,46 ; p<0,01)$ пацієнтів із ВІЛ-асоційованими неврологічними захворюваннями. Підвищення концентрації IFN-y у сироватці крові також асоціювалось 3 високим рівнем в крові РНК-копій $(r s=0,32 ; p<0,05)$ та зменшенням кількості клітин CD4 (rs=-0,29; p<0,05). За результатами ROC-аналізу визначено, що високий ризик несприятливого перебігу ВІЛ-асоційованої інфекції ЦНС прогнозується при концентрації IFN-y у спинномозковій рідині

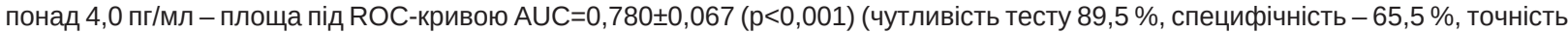
- 75,0 \%). Висока імовірність розвитку церебрального туберкульозу прогнозується при підвищенні концентрації IFN-y у CMP

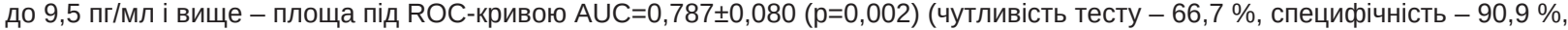

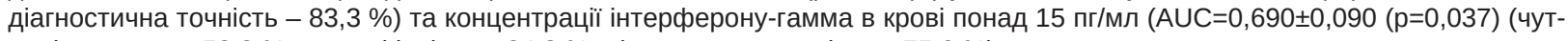
ливість тесту - 53,3 \%, специсрічність - 84,8 \%, діагностична точність - 75,0 \%).

Висновки. Високий вміст інтерферону-гамма у спинномозковій рідині є важливим критерієм для діагностики туберкульозного ураження ЦНС. Більший рівень IFN-y у спинномозковій рідині при летальному наслідку може бути предиктором несприятливого розвитку неврологічних захворювань у пацієнтів із ВІЛ. Враховуючи отримані дані кореляційного і дисперсійного аналізу, можна припустити, що визначення IFN-y у комплексі з імунологічними показниками та вірусним навантаженням ВІЛ РНК у крові та СМР підвищить його діагностичну та прогностичну цінність.
\end{abstract}

Ключові слова: ВІЛ-інфекція; ВІЛ-асоційовані неврологічні захворювання; інтерферон-гамма (IFN-y); спинномозкова рідина; ROC-аналіз.

ВСТУП Неврологічні захворювання розвиваються у більшості пацієнтів із ВІЛ та можуть бути пов'язані як 3 безпосередньою дією вірусу (нейрокогнітивний розлад), так і з опортуністичними інфекціями в результаті прогресування імуносупресії. За даними досліджень, пацієнти з наявністю неврологічних порушень мають значно вищий ризик смертності, а більша частина летальних випадків зумовлена опортуністичними інорекціями ЦНС [1]. Труднощі у диференційній діагностиці та в прогнозуванні наслідків захворювань нервової системи, пов'язаних із ВІЛ, потребують детального аналізу складових патогенетичного процесу.

Інтерферон-гамма (IFN-y) є одним із головних цитокінів, що має важливе значення для розвитку нейропатогенезу ВІЛ [2]. Доведено, що інфрікування ВІЛ призводить до дизрегуляції просрілю цитокінів. Виробництво IFN-у спостерігається як у CD4, так і в CD8 клітинних групах. Існують роботи, в яких показано, що IFN-у відноситься до біфрункціональних цитокінів, які надають як інгібуючу, так і стимулюючу дії на ВІЛ-1 [3], тому дані про кількісні зміни IFN-y достатньо суперечливі. IFN-y відіграє роль ключового медіатора при запальних демієлінізуючих захворюваннях. Він надає плеотрофрічні ефекти, які можуть бути частиною механізму, що приводить до деменції при інфрікуванні ВIЛ-1 [4]. Доведено, що GIF збільшує продукцію TNF- $\alpha$ i IL-1, що призводить до подальшого посилення реплікації ВІЛ-1 [5]. Є дані, які доводять, що астроцити, активовані IFN-y, інгібують T. gondii [6]. Інтерферон-гамма-асоційована стимуляція макрофагів призводить до збільшення секреції неоптерину, який пов'язаний із прогресуванням ВІЛ-інфекції ЦНС, при цьому підвищується вироблення хінолінової кислоти та конвульсанта [7]. Існують також відомості про зміни рівня IFN-y у біологічних рідинах пацієнтів із мікобактеріальною інфекцією, пов'язані з тим, що даний цитокін $є$ продуктом активної клітинної імунної відповіді, яка викликана Mycobacterium tuberculosis [8]. Так, в роботі S. K. Sharma \& Amit Banga (2004) визначено, що рівень IFN-у у плевральній рідині значно вищий при туберкульозному плевриті, ніж при плевриті іншої етіології і, таким чином, оцінка рівня IFN-y в плевральній рідині $\epsilon$ важливою для розмежування пацієнтів із туберкульозом [9]. Разом з тим, даних про роль зазначеного цитокіну в 
СМР при ВІЛ-асоційованих захворюваннях ЦНС недостатньо, а відомості, які існують про зміни IFN-у в крові, достатньо суперечливі, що потребує подальшого дослідження вмісту даного біомаркера у спинномозковій рідині (CMP) і в крові та вивчення його взаємозв'язку з показниками імунологічного статусу та вірусного навантаження 3 метою поліпшення диференційної діагностики схожих за клінічною картиною інфекційних уражень головного мозку та прогнозування їх наслідків у ВІЛ-інфікованих пацієнтів.

Метою дослідження було вивчити зміни вмісту IFN-y в крові й спинномозковій рідині та дослідити його зв'язок з імунологічним статусом та вірусним навантаженням РНК-ВІЛ при ВІЛ-асоційованих неврологічних захворюваннях.

МАТЕРІАЛИ I МЕТОДИ Вибірку дослідження склали 48 пацієнтів із ВІЛ-інфрекцією та захворюваннями ЦНС, зумовленими опортуністичними інфекціями, у віці 21-54 роки, середній вік Me (LQ - HQ) - 38 (34-46) років. Серед них було 25 (52,1\%) пацієнтів чоловічої і 23 (47,9\%) жіночої статей. В структурі виявлених ВІЛ-асоційованих захворювань ЦНС переважали церебральний туберкульоз - 15 (31,3 \%) і вірусні енцефаліти, зумовлені вірусом Епштейна-Барр (EBV), цитомегаловірусом (CMV), вірусом простого герпесу (HSV) - 11 (22,9\%), (ЕБВ, ЦМВ, HSV) - 11 (22,9 \%) пацієнтів. Енцесраліти неуточненої етіології мали місце у 9 (18,7 \%) пацієнтів, токсоплазмоз ЦНС - в 7 (14,6\%), ураження грибкової етіології (кандидоз, криптококоз) - у 6 (12,5 \%). Групу порівняння склали 7 здорових донорів (4 чоловіки і 3 жінки) віком від 25 до 46 років. Усі виділені групи були статистично порівняними між собою за віком пацієнтів і гендерним складом $(p>0,05)$.

Вміст IFN-y в крові та у CMP визначали за методом ІФА з використанням діагностичних наборів АО "ВекторБест". Визначення ВІЛ РНК у СМР та плазмі крові (ЕДТА) здійснювали за методом ПЛР із детекцією в режимі реального часу за стандартизованою технологією.

Для статистичної обробки результатів дослідження використовували пакети програм Statistica v.6.1® i MedCalc v.11.5.0 (free download). Враховуючи невелику чисельність вибірок дослідження, використовували непараметричні характеристики і методи порівняння: медіану (Me), інтерквартильний розмах (LQ - HQ), критерії Манна-Уїтні (U), хі-квадрат Пірсона $\left(X^{2}\right)$ і двосторонній точний критерій Фішера (FET). Для оцінки взаємозв'язку між ознаками проводили кореляційний аналіз із розрахунком коефіцієнтів рангової кореляції Спірмена $\left(r_{s}\right)$, багатофракторний дисперсійний аналіз (Main effects ANOVA) із розрахунком показника (К, \%), що характеризує ступінь впливу кожного незалежного фрактора (наслідок захворювання, нозологічна фрорма) на досліджувану ознаку, а також ROC-аналіз для оцінки дискримінаційної значимості показників, які вивчали, для прогнозування перебігу неврологічного захворювання [9]. Критичний рівень статистичної значимості при перевірці гіпотез приймали $<5 \%(p<0,05)$.

РЕЗУЛЬТАТИ ДОСЛІДЖЕНЬ ТА ЇХ ОБГОВОРЕННЯ Під час дослідження визначено загальні та клініко-анамнестичні особливості ВІЛ-асоційованих захворювань ЦНС. По-перше, більшість пацієнтів - 29 (60,4 \%) виписали 3 лікарні з поліпшенням стану, а 19 (39,6 \%) - із тяжким перебігом захворювання померли внаслідок неврологічних захворювань. Серед останніх переважали чоловіки - 14 з 19 (73,7 \%). Летальність була високою серед пацієнтів із церебральним туберкульозом (9 осіб - 60,0 \%) і грибковими ураженнями ЦНС (4-66,7 \%), що перевищувало такий відсоток при всіх інших неврологічних захворюваннях - 6 (22,2\%) пацієнтів ( $p=0,021$ i $\mathrm{p}=0,053$ за критерієм FET).

У 21 хворого (43,8 \%) з ВІЛ-асоційованими захворюваннями ЦНС ВІЛ-статус було визначено у той же рік або одночасно з появою неврологічних симптомів, переважно у померлих пацієнтів - 63,2 \% проти 31,0 \% (p=0,039 FET). Середній час від виявлення ВІЛ до неврологічних проявів становив 1 рік $(0-4,5)$, у тому числі 3 (0-6) роки у виписаних пацієнтів і 0 (0-1) років у померлих ( $p=0,009$ за U-критерієм). 3'ясовано, що 43,8 \% пацієнтів інфрікувались при внутрішньовенному вживанні наркотиків, 35,4 $\%$ - статевим шляхом, а у кожного п'ятого хворого $(20,8$ \%) не вдалося встановити шлях інфікування ВІЛ, у тому числі в 26,3 \% померлих і 17,2 \% виписаних пацієнтів ( $p=0,343$ FET), що корелювало 3 пізньою діагностикою ВІЛ-інфекції $\left(r_{s}=0,29 ; p<0,05\right)$.

Аналіз показників імунологічного статусу і вірусного навантаження показав високий рівень імуносупресії і кількості ВІЛ РНК у плазмі крові (VL) та CMP (VLs) пацієнтів із ВІЛ-асоційованими захворюваннями ЦНС (табл. 1). Понад половини хворих (30-62,5 \%) мали рівень CD4 менше 50 кл/мкл; медіана CD4 склала 32 (10-64) кл/мкл, 3 них у пацієнтів, які померли, - 20 (6-46) кл/мкл проти 50 (22-65) кл/мкл в осіб, які вижили (p=0,045 U). При летальному наслідку хвороби середні показники вірусного навантаження ВІЛ PHK ( $\mathrm{Lg}$ VL - 5,14 коп/мл у CMP і 5,60 коп/мл у плазмі крові) також вірогідно перевищували аналогічні дані у пацієнтів, яких виписали з поліпшенням стану - Lg VL 4,31 коп/мл у CMP і 5,10 коп/мл у крові ( $p=0,029$ і $p=0,049 U$ ), що відповідало повній відсутності АРТ до початку маніфестації неврологічних захворювань у померлих пацієнтів ( $p<0,001$ FET).

Мінімальні рівні CD4 у крові на тлі високих показників навантаження ВІЛ РНК у крові й СМР відзначались в групах хворих із грибковими ураженнями ЦНС і церебральним туберкульозом (табл. 2), що також узгоджується з тяжкістю стану хворих в цих групах, про що наголошено вище.

Таблиця 1. Лабораторні характеристики пацієнтів із ВІЛ-асоційованими захворюваннями цНС залежно від наслідку хвороби (абс./ \% або Me (LQ-HQ))

\begin{tabular}{|c|c|c|c|c|c|}
\hline \multicolumn{2}{|l|}{ Показник } & $\begin{array}{l}\text { Усі пацієнти } \\
(\mathrm{n}=48)\end{array}$ & $\begin{array}{c}\text { Пацієнти, } \\
\text { які вижили }(\mathrm{n}=29)\end{array}$ & $\begin{array}{c}\text { Пацієнти, } \\
\text { які померли }(\mathrm{n}=19)\end{array}$ & \begin{tabular}{|c|} 
Відмінність між \\
групами (p)
\end{tabular} \\
\hline \multirow{2}{*}{$\begin{array}{l}\text { CD4+, кл/мкл на початку манісрестації } \\
\text { неврологічних захворювань }\end{array}$} & $0-50$ & $30 / 62,5$ & $15 / 51,7$ & $15 / 78,9$ & 0,073 (FET) \\
\hline & Медіана & $32(10-64)$ & $50(22-65)$ & $20(6-46)$ & $0,045(U)$ \\
\hline \multicolumn{2}{|l|}{ ВІЛ PHК Lg VLs (CMP) (коп/мл) } & $4,70(3,75-5,63)$ & $4,31(3,00-5,06)$ & $5,14(4,39-5,99)$ & $0,029(U)$ \\
\hline \multicolumn{2}{|l|}{ ВІЛ PHK Lg VL (кров) (коп/мл) } & $5,39(4,83-5,86)$ & $5,10(3,85-5,83)$ & $5,60(5,25-5,99)$ & $0,049(U)$ \\
\hline \multicolumn{2}{|l|}{ IFN-y (кров) (пг/мл) } & $10,0(4,0-18,0)$ & $7,0(3,0-15,0)$ & $10,0(6,0-22,0)$ & $0,277(U)$ \\
\hline \multicolumn{2}{|l|}{ IFN-y (СМР) (пг/мл) } & $5,5(1,9-10,0)$ & $3,0(1,0-7,0)$ & $9,0(6,0-12,0)$ & $0,001(U)$ \\
\hline
\end{tabular}


ISSN 1681-276Х. ВІСНИК НАУКОВИХ ДОСЛІДЖЕНЬ. 2018. № 1

Таблиця 2. Характеристики хворих із ВІЛ-асоційованими захворюваннями цНС (абс./ \% або Ме (LQ-HQ))

\begin{tabular}{|c|c|c|c|c|c|}
\hline \multirow[b]{2}{*}{ Показник } & \multicolumn{5}{|c|}{ Захворювання ЦНС } \\
\hline & $\begin{array}{c}\text { грибкові ураження } \\
(\mathrm{n}=6)\end{array}$ & $\begin{array}{c}\text { туберкульоз } \\
(\mathrm{n}=15)\end{array}$ & $\begin{array}{l}\text { токсоплазмоз } \\
(n=7)\end{array}$ & $\begin{array}{c}\text { вірусні енцефаліти } \\
(\mathrm{EBV}, \mathrm{HSV}, \mathrm{CMV})(\mathrm{n}=11)\end{array}$ & $\begin{array}{c}\text { енцесраліти неуточ- } \\
\text { нені }(\mathrm{n}=9)\end{array}$ \\
\hline $\begin{array}{l}\text { ВІЛ РНК Lg VLs (CMP) } \\
\text { (коп/Мл) }\end{array}$ & $\begin{array}{c}4,96 \\
(4,18-5,30)\end{array}$ & $\begin{array}{c}5,79 \\
(4,16-6,09) \\
\text { p 4,5 }\end{array}$ & $\begin{array}{c}4,49 \\
(4,0-5,84)\end{array}$ & $\begin{array}{c}4,28 \\
(3,59-4,8) \\
\text { p } 2\end{array}$ & $\begin{array}{c}4,51 \\
(2,66-4,94) \\
\text { p } 2\end{array}$ \\
\hline $\begin{array}{l}\text { ВІЛ PHK Lg VL (кров) } \\
\text { (коп/мл) }\end{array}$ & $\begin{array}{c}5,55 \\
(5,42-5,66)\end{array}$ & $\begin{array}{c}5,82 \\
(4,83-6,09) \\
\text { p 5 }\end{array}$ & $\begin{array}{c}5,04 \\
(3,63-5,81)\end{array}$ & $\begin{array}{c}5,25 \\
(4,16-5,8)\end{array}$ & $\begin{array}{c}5,19 \\
(3,76-5,51) \\
\text { p 2 }\end{array}$ \\
\hline CD4+ (кл/мкл) & $\begin{array}{c}19(5-42) \\
\text { p } 3\end{array}$ & $\begin{array}{c}20(6-63) \\
\text { p } 3\end{array}$ & $\begin{array}{l}60(50-73) \\
\text { p } 1,2,5\end{array}$ & $46(7-158)$ & $\begin{array}{c}30(13-53) \\
\text { p } 3\end{array}$ \\
\hline IFN-y (CMP) (пг/мл) & $\begin{array}{c}9,0 \\
(6,0-12,0) \\
\text { p } 3,4,5 \\
\end{array}$ & $\begin{array}{c}11,0 \\
(5,0-25,0) \\
\text { p } 3,4,5 \\
\end{array}$ & $\begin{array}{c}4,0 \\
(1,0-5,0) \\
\text { p } 1,2 \\
\end{array}$ & $\begin{array}{c}4,5 \\
(1,8-7,0) \\
\text { p } 1,2 \\
\end{array}$ & $\begin{array}{c}1,8 \\
(0,9-4,0) \\
\text { p } 1,2 \\
\end{array}$ \\
\hline IFN-y (кров) (пг/мл) & $\begin{array}{c}10,5 \\
(6,0-15,0) \\
\text { p } 2\end{array}$ & $\begin{array}{c}18,0 \\
(6,0-39,0) \\
\text { p } 1,3,5\end{array}$ & $\begin{array}{c}7,0 \\
(4,5-10,5) \\
\text { p2 }\end{array}$ & $\begin{array}{c}10,0 \\
(3,0-21,0)\end{array}$ & $\begin{array}{c}3,0 \\
(1,8-14,0) \\
\text { p } 2\end{array}$ \\
\hline
\end{tabular}

Примітка. p 1,2,3,4,5 - p<0,05 між відповідними групами.

Враховуючи важливу роль інтерферону-гамма (IFN-y) при ВІЛ-інфекції та неврологічних захворюваннях, ми провели точний аналіз вмісту цього цитокіну в крові та CMP тематичних пацієнтів та імовірних зв'язків IFN-y 3 клінічними і лабораторними показниками. Визначено суттєві розбіжності між рівнем IFN-y у CMP залежно від наслідку хвороби - медіана показника у померлих пацієнтів втричі перевищувала таку у хворих, які вижили - 9,0 $(6,0-12,0)$ пг/мл проти 3,0 $(1,0-7,0)$ пг/мл, відповідно ( $\mathrm{p=0,001}$ за U-критерієм), тобто високий рівень IFN-y у лікворі прямо корелював з тяжкістю стану хворих із ВІЛасоційованими захворюваннями ЦНС та несприятливим прогнозом $\left(r_{s}=0,48 ; p<0,001\right)$. Разом 3 тим, відмінності між рівнями сироваткового IFN-y у таких хворих мали тільки характер тенденції - 10,0 (6,0-12,0) пг/мл проти 7,0 $(3,0-15,0)$ пг/мл, відповідно при летальному і сприятливому наслідку хвороби ( $\mathrm{p}=0,277 \mathrm{U})$ (табл. 1).

За даними кореляційного аналізу встановлено прямі взаємозв'язки між вмістом IFN-y у CMP і вірусним навантаженням ВІЛ РНК як у СМP $\left(r_{s}=0,44 ; p<0,01\right)$, так і в крові $\left(r_{s}=0,46 ; p<0,01\right)$ пацієнтів із ВІЛ-асоційованими захворюваннями ЦНС. Підвищення концентрації інтерферону-гамма в сироватці крові також асоціювалось 3 високим рівнем у крові РНК-копій $\left(r_{s}=0,32 ; p<0,05\right)$ та зменшенням кількості клітин CD4 ( $\left.r_{\mathrm{s}}=-0,29 ; \mathrm{p}<0,05\right)$.

Незважаючи на наявність достовірної кореляції між вмістом IFN-у в крові й CMP у хворих із ВІЛ-інфекцією та неврологічними захворюваннями ЦНС $\left(r_{s}=0,38 ; p<0,01\right)$, більш інформативним маркером негативного прогнозу може бути рівень IFN-y у CMP. Зокрема, за результатами ROC-аналізу встановлено, що високий ризик несприятливого перебігу ВІЛ-асоційованої інфекції ЦНС прогнозується при концентрації IFN-y у спинномозковій рідині понад 4,0 пг/мл-площа під ROC-кривою $A U C=0,780 \pm 0,067$ ( $p<0,001)$, що забезпечує чутливість тесту 89,5\%, специфрічність - 65,5\%, точність - 75,0 \% (рис. 1).

Як видно з таблиці 2, інтерферон-гамма виявився інформативним біомаркером ВІЛ-асоційованих захворювань ЦНС. Його вміст у крові хворих із ВІЛ-інфеекцією перевищував показники донорів (медіана 2,0 (1,1-2,2) пг/ мл) від 1,5 до 9 разів (від $p<0,05$ до p<0,001) з найбільшим значенням при туберкульозному ураженні ЦНС - 18,0 $(6,0-39,0)$ пг/мл (рис. 3). Найбільш вираженим підвищен- ня концентрації IFN-y у CMP спостерігалось у хворих на туберкульоз ЦНС (медіана 11,0 $(5,0-25,0)$ пг/мл) і грибкові ураження $(9,0$ (6,0-12,0) пг/мл). Ці показники вірогідно перевищували рівень інтерферону-гамма при інших захворюваннях (церебральний токсоплазмоз, енцесраліти) $\mathrm{p}<0,05$.

Для уточнення ролі етіологічного чинника ураження ЦНС та тяжкості перебігу захворювання у підвищенні рівня інтерферону-гамма у крові й СМР було проведено багатофракторний дисперсійний аналіз (Main effects ANOVA). Встановлено, що домінуючу роль у цих змінах відіграє туберкульозна інфрекція - ступінь її впливу (К) на мінливість рівнів IFN-у у крові хворих становить 13,9\% (p=0,008), в CMP - 24,8\% ( $<<0,001)$, разом 3 тим, як окремий внесок тяжкості стану хворих в ті зміни менше 1,5\% ( $>>0,05)$. Отримані результати дозволили розглядати рівень IFN-y у крові й лікворі як інформативний маркер туберкульозного ураження ЦНС у ВІЛ-інфрікованих хворих.

ROC- крива (GIF у CMP)

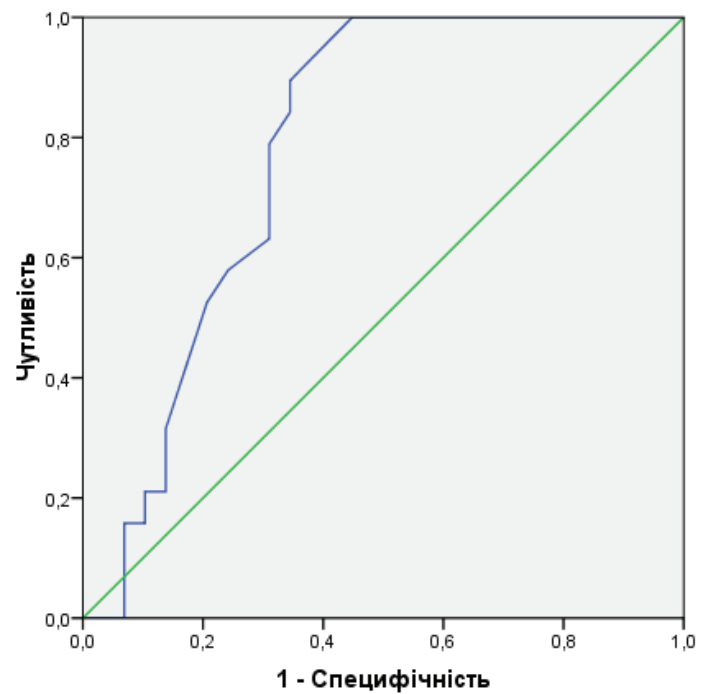

Pиc. 1. ROC-крива оцінки дискримінаційної значимості рівнів IFN-y у спинномозковій рідині для прогнозування несприятливого перебігу ВІЛ-асоційованої інфекції ЦНС. 


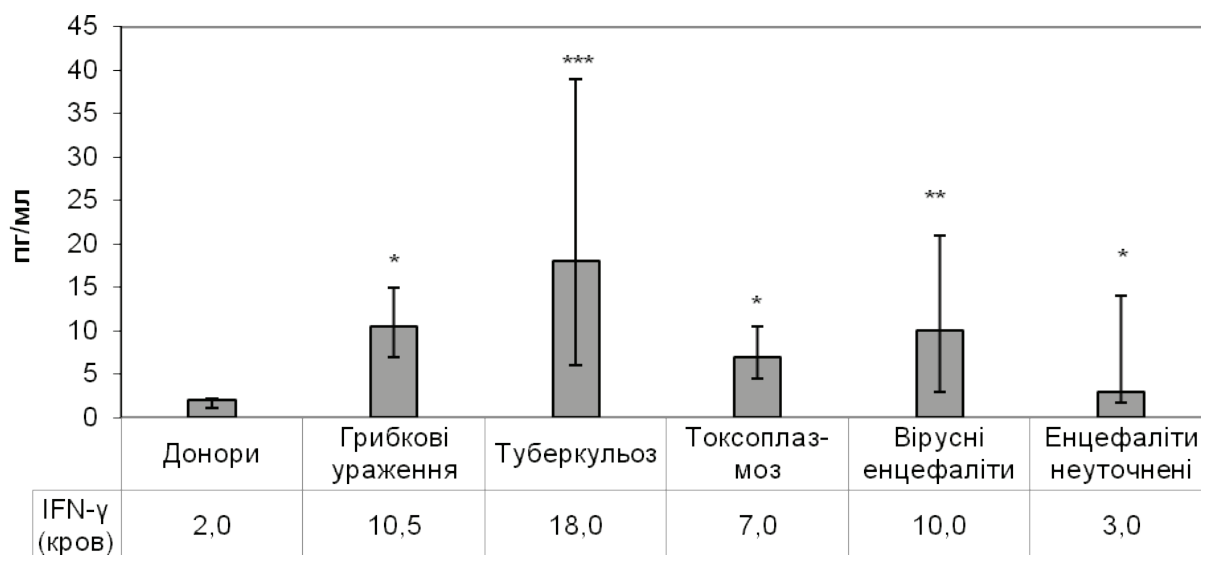

Рис. 3. Середні рівні IFN-y у крові пацієнтів тематичних груп: указано Me (LQ-HQ).

Примітка. * $-p<0,05,{ }^{* *}-p<0,01,{ }^{* \star *}-p<0,001$ порівняно 3 групою донорів.

За результатами ROC-аналізу було визначено, що висока ймовірність розвитку церебрального туберкульозу прогнозується при підвищенні концентрації IFN-y у CMP до 9,5 пг/мл і вище - площа під ROC-кривою AUC $=0,787 \pm 0,080(p=0,002), 3$ показниками чутливості тесту - 66,7 \%, специфрічності - 90,9 \%, діагностичної точності - 83,3 \%. Критерієм туберкульозного ураження ЦНС у ВІЛ-інфрікованих хворих може бути вміст інтерферону-гамма у крові понад 15 пг/мл (AUC=0,690 $\pm 0,090$ ( $p=0,037)$, з показниками чутливості тесту $-53,3 \%$, специфрічності - 84,8 \%, діагностичної точності - 75,0 \%.

Щодо інших нозологічних фрорм ураження ЦНС (грибкові ураження, токсоплазмоз ЦНС, вірусні й неуточнені енцесраліти), то результати дослідження показують, що при більшій кількості спостережень в означених групах, відмінності рівня IFN-y можуть досягти критичного рівня статистичної значимості $(p<0,05)$ для диференційної діагностики даних нозологічних фрорм.

\section{СПИСОК ЛІТЕРАТУРИ}

1. Neurologic disease burden in treated HIVIAIDS predicts survival A population-based study / P. Vivithanaporn, G. Heo, J. Gamble, [et al.] // Neurology. - 2010. - Vol. 75. - No. 13. P. 1150-1158.

2. Carroll-Anzinger D.Gamma interferon primes productive human immunodeficiency virus infection in astrocytes / D. Carroll-Anzinger, L. Al-Harthi // Journal of virology. - 2006. - Vol. 80. - No. 1. P. 541-544.

3. Kedzierska K. Cytokines and HIV-1: interactions and clinical implications / Katherine Kedzierska, M. Suzanne // Antiviral Chemistry and Chemotherapy. - 2001. - Vol. 12. - No.3 - P. 133-150.

4. Olsson T. Cytokines in neuroinflammatory disease: role of myelin autoreactive T cell production of interferon-gamma / T. Olsson // Journal of Neuroimmunology. - 1992. - Vol. 40. - No 2. - P. 211-218.

5 . Spontaneous cytotoxicity and tumor necrosis factor production by peripheral blood monocytes from AIDS patients / S. C. Wright, A. Jewett, R. Mitsuyasu, B. Bonavida // J. Immunol. - 1988. Vol. 141. - P. 99-104.
ВИСНОВКИ Вміст інтерферону-гамма у спинномозковій рідині 9,5 пг/мл та вище може бути важливим критерієм для діагностики ураження ЦНС, спричиненого М. Tuberculosis. Значно вищий рівень IFN-у у спинномозковій рідині при летальному наслідку хвороби може бути предиктором несприятливого розвитку неврологічних захворювань у пацієнтів із ВІЛ, ніж у хворих, яких виписали з поліпшенням стану. Відмінності показника IFN-y в крові та СМР, за умов більшої кількості спостережень, надають змогу його використовувати для диференційної діагностики різних нозологічних фрорм. Враховуючи отримані дані кореляційного і дисперсійного аналізу, можна припустити, що визначення IFN-y у комплексі з імунологічними показниками та вірусним навантаженням ВІЛ РНК у крові та СМР може підвищити його діагностичну та прогностичну цінність.

6. Halonen S. K. Investigation into the mechanism of gamma interferon-mediated inhibition of Toxoplasma gondii in murine astrocytes / S. K. Halonen, L. M. Weiss // Infection and Immunity. - 2000. - Vol. 68. - No. 6. - P. 3426-3430.

7. Heyes M. P. Human macrophages convert L-tryptophan into the neurotoxin quinolinic acid / M. P. Heyes, K. Saito, S. L. Markey // J. Biochem. - 1992. - Vol. 83. -P. 633-635.

8. Induction of gamma interferon production in human alveolar macrophages by Mycobacterium tuberculosis / M. J. Fenton, M. W. Vermeulen, M. W. Kim [et al.] // Infection and Immunity. - 1997. - Vol. 65 (12). - P. 5149-5156.

9. Sharma S. K. Diagnostic utility of pleural fluid IFN-y in tuberculosis pleural effusion / S. K. Sharma, A. Banga // Journal of Interferon \& Cytokine Research. - 2004. - Vol. 24, No. 4. - P. 213-217.

10. Юнкеров В. И. Математико-статистическая обработка данных медицинских исследований / В. И. Юнкеров, С. Г. Григорьев, М. В. Резванцев. - СПб. : ВМедА, 2011. - 320 с.

Отримано 22.12.17 


\author{
@K. Yu. Lytvyn ${ }^{1}$, L. R. Shostakovych-Koretskaya ${ }^{1}$, L. O. Havrylenko \\ Dnipropetrovsk Medical Academy of Ministry of Health of Ukraine ${ }^{1}$ \\ Prof. E. H. Popkov Dnipropetrovsk Municipal Hospital No. $21^{2}$
}

\title{
DIAGNOSTIC AND PROGNOSTIC VALUE OF DETERMINATION OF INTERFERON-GAMMA IN CEREBROSPINAL FLUID IN HIV-ASSOCIATED NEUROLOGICAL DISEASES
}

Summary. Neurological diseases develop in majority of patients with HIV, lead to high mortality, the predominant part of which is due to opportunistic infections of the central nervous system (CNS). Interferon-gamma (IFN-y) is one of the major cytokines that are important for the development of HIV neuropathogenesis.

The aim of the study - to investigate changes in the content of IFN-y in blood and cerebral spinal fluid (CSF) and to investigate its association with the immunological status and viral load of HIV RNA in HIV-associated neurological diseases

Materials and Methods. 48 patients with HIV infection and central nervous system disorders due to opportunistic infections, aged 21 to 54 years old, were examined. In the structure of disorders of the central nervous system, cerebral tuberculosis prevailed - 15 $(31.3 \%)$ patients and viral encephalitis (EBV, CMV, HSV) - 11 (22.9\%) patients. The comparison group consisted of 7 healthy donors of the corresponding age. The content of IFN-y in the blood and in the CSF was determined by the ELISA method. Statistica v.6.1巴 and MedCalc v.11.5.0 (free download) were used for statistical analysis of the results of the study.

Results and Discussion. Significant differences were found between the content of IFN-y in CSF, depending on the outcome of the disease - the median of the indicator in lethal cases was three times higher than that in surviving patients $-9.0(6.0-12.0) \mathrm{pg} / \mathrm{ml}$ versus $3.0(1.0-7.0) \mathrm{pg} / \mathrm{ml}(\mathrm{p}=0.001$ for the U-criterion), that is, the high level of IFN-y in the cerebrospinal fluid directly correlated with the severity of the patient's condition and unfavorable prognosis $(r s=0.48 ; p<0.001)$. Direct correlations were found between the content of IFN-y in CSF and the viral load of HIV RNA, both in CSF ( $r s=0.44 ; p<0.01)$ and in blood ( $r s=0.46 ; p<0.01)$ of patients with HIV-associated neurological diseases. An increase in the concentration of IFN-y in serum was also associated with a high level of RNA copies ( $r s=0.32 ; p<0.05$ ) and a decrease in the number of CD4 cells ( $r s=-0.29 ; p<0.05$ ). According to the results of the $\mathrm{ROC}$ analysis, it is determined that the high risk of an unfavorable course of HIV-associated CNS infection is predicted at an IFN-y concentration in the cerebrospinal fluid of more than $4.0 \mathrm{pg} / \mathrm{ml}$; the area under the ROC curve is AUC $=0.780 \pm 0.067(p<0.001)$ (sensitivity of the test $89.5 \%$, specificity $-65.5 \%$, accuracy $-75.0 \%$ ). The high probability of developing cerebral tuberculosis is predicted by increasing the concentration of IFN-y in the CSF to $9.5 \mathrm{pg} / \mathrm{ml}$ and above - the area under the ROC curve AUC $=0.787 \pm 0.080$ $(p=0.002)$ (sensitivity of the test $66.7 \%$, specificity $-90.9 \%$, diagnostic accuracy $-83.3 \%$ ) and the concentration of interferon gamma in the blood of more than $15 \mathrm{pg} / \mathrm{ml}$ (AUC $=0.690 \pm 0.090(\mathrm{p}=0.037)$ (sensitivity of the test $53.3 \%$, specificity $-84.8 \%$ diagnostic accuracy $-75.0 \%)$.

Conclusions. The high content of interferon-gamma in the cerebrospinal fluid is an important criterion for diagnosis of tuberculous lesion of the central nervous system. The increased level of IFN-y in the cerebrospinal fluid accompanied by lethal outcome may be a predictor of the unfavourable progression of neurological disorders in HIV patients. Taking into account the obtained data of correlation and dispersion analysis, it can be assumed that the definition of IFN-y in a complex with immunological parameters and viral load of HIV RNA in blood and CSF will increase its diagnostic and predictive value.

Key words: HIV infection; HIV-associated neurological diseases; interferon-gamma (IFN-y); cerebral spinal fluid (CSF); ROC-analysis.

СК. Ю. Литвин ${ }^{1}$, Л. Р. Шостакович-Корецка ${ }^{1}$, Л. А. Гавриленко ${ }^{2}$

гУ “Днепропетровская медицинская академия Мз Украины” КУ “Днепропетровская городская клиническая больница № 21 имени проф. Е. Г. Попковой Днепропетровского областного совета" 2

\section{ДИАГНОСТИЧЕСКОЕ И ПРОГНОСТИЧЕСКОЕ ЗНАЧЕНИЕ ОПРЕДЕЛЕНИЯ ИНТЕРФЕРОНА-ГАММА В СПИННОМОЗГОВОЙ ЖИДКОСТИ ПРИ ВИЧ-АССОЦИИРОВАННЫХ НЕВРОЛОГИЧЕСКИХ ЗАБОЛЕВАНИЯХ}

Резюме. Неврологические заболевания развиваются у большинства пациентов с ВИч, имеют высокую летальность, подавляющее долю которой составляют оппортунистические инфекции ЦНС. Интерферон-гамма (IFN-y) является одним из главных цитокинов, имеющих важное значение для развития нейропатогенеза ВИч.

Цель исследования - изучить изменения содержания IFN-ү в крови и спинномозговой жидкости и исследовать его связь с иммунологическим статусом и вирусной нагрузкой ВИЧ РНК при ВИЧ-ассоциированных неврологических заболеваниях.

Материалы и методы. Обследовано 48 пациентов с ВИЧ-иноекцией и заболеваниями ЦНС, обусловленными оппортунистическими инфекциями, в возрасте 21-54 лет. В структуре заболеваний ЦНС преобладали церебральный туберкулез - 15 $(31,3$ \%) и вирусные энцефалиты (ЭБВ, ЦМВ, HSV) - 11 (22,9 \%) пациентов. Группу сравнения составили 7 здоровых доноров соответствующего возраста. Содержание IFN-y в крови и в спинномозговой жидкости (СМЖ) определяли методом ИФА. Для статистической обработки результатов исследования использовали программы Statistica v.6.1® и MedCalc v.11.5.0 (free download).

Результаты исследований и их обсуждение. Определены существенные расхождения между содержанием IFN-y в CMж в зависимости от исхода заболевания - медиана показателя в умерших пациентов в три раза превышала таковую у больных, выживших, - 9,0 (6,0-12,0) пг/мл против 3,0 (1,0-7,0) пг/мл (p=0,001 по U-критерию), то есть высокий уровень IFN-у в ликворе прямо коррелировал с тяжестью состояния больных и неблагоприятным прогнозом (rs=0,48; p<0,001). Установлены прямые взаимосвязи между содержанием IFN-y в СМЖ и вирусной нагрузкой Вич РНК как в CMЖ (rs=0,44; p<0,01), так и в крови ( $r s=0,46 ; p<0,01)$ пациентов с ВИЧ-ассоциированными неврологическими заболеваниями. Повышение концентрации IFN-y в сыворотке крови также ассоциировалось с высоким уровнем в крови РНК-копий (rs=0,32; p<0,05) и уменьшением количества клеток CD4 (rs=-0,29; p<0,05). По результатам ROC-анализа определено, что высокий риск неблагоприятного течения Вичассоциированной инфекции ЦНС прогнозируется при концентрации IFN-y в спинномозговой жидкости более 4,0 пг/мл - пло-

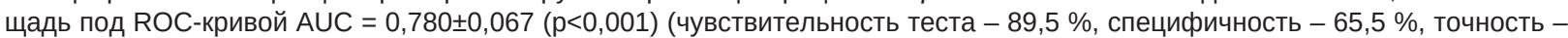
75,0 \%). Высокая вероятность развития церебрального туберкулеза прогнозируется при повышении концентрации IFN-y в 


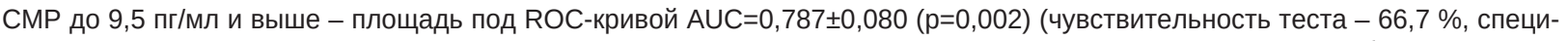
фричность - 90,9 \%, диагностическая точность - 83,3 \%) и концентрации интерферона-гамма в крови более 15 пг/мл (AUC=0,690 $\pm 0,090$ ( $p=0,037$ ) (чувствительность теста - 53,3 \%, специфичность - 84,8 \%, диагностическая точность - 75,0 \%). Выводы. Высокое содержание интерферона-гамма в спинномозговой жидкости является важным критерием для диагностики туберкулезного поражения ЦНС. Более высокий уровень IFN-y в спинномозговой жидкости при летальном исходе может быть предиктором неблагоприятного развития неврологических заболеваний у пациентов с ВИЧ. Учитывая полученные данные корреляционного и дисперсионного анализа, можно предположить, что определение IFN-y в комплексе с иммунологическими показателями и вирусной нагрузкой ВИЧ РНК в крови и СМЖ повысит его диагностическую и прогностическую ценность.

Ключевые слова: ВИЧ-инфекция; ВИЧ-ассоциированные неврологические заболевания; интерферон-гамма (IFN-ү); спинномозговая жидкость; ROC-анализ. 